\title{
Effects of Tissue Phosphorus and Nitrogen in Impatiens wallerana on Western Flower Thrips (Frankliniella occidentalis) Population Levels and Plant Damage
}

Yan Chen ${ }^{1}$ and Kimberly A. Williams ${ }^{2}$

Department of Horticulture, Forestry, and Recreation Resources, Kansas State University, Manhattan KS 66506-5506

Brent K. Harbaugh ${ }^{3}$ and Michelle L. Bell ${ }^{4}$

Gulf Coast Research and Education Center, University of Florida, Bradenton, FL 34207

Additional index words. integrated pest management, plant nutrition

Abstract. Host-plant nutritional status may affect the incidence and development of western flower thrips (WFT; Frankliniella occidentalis Pergande). Two greenhouse experiments were conducted to determine the responses of WFT population levels on impatiens (Impatiens wallerana Hook.f.) when plants were fertilized with commercially practiced rates of nitrogen $(\mathbf{N})$ and phosphorus (P). Impatiens 'Dazzler Violet' were grown with nutrient treatment combinations of $2 \mathrm{~N}$ rates $(8$ and $20 \mathrm{~mm})$ by $2 \mathrm{P}$ rates $(0.32$ and $1.28 \mathrm{~mm})$. Individual plants grown in thrips-proof cages were inoculated with WFT at 2 or 4 weeks after transplant, in separate experiments, representing vegetative or reproductive stages of plant growth, respectively. Plants were destructively sampled weekly for 4 weeks following inoculation. Plant tissue $\mathbf{N}$ and $P$ concentrations were significantly different across treatments: 8 and $20 \mathrm{~mm} N$ resulted in $4.9 \%$ and $6.3 \% \mathrm{~N}$ in tissue, respectively; 0.32 and $1.28 \mathrm{~mm} P$ resulted in $0.37 \%$ and $0.77 \%$ $P$ in tissue, respectively. Nitrogen rates had no effect on WFT population levels. However, 4 weeks after inoculation with adult female WFT during the vegetative growth stage, plants fertilized with $1.28 \mathrm{~mm} P$ had more adult WFT than those fertilized with $0.32 \mathrm{~mm}$ P. Feeding damage varied depending on whether plants were inoculated in the vegetative stage with adult WFT or during reproductive growth with immature WFT. Plant size and number of flowers were lower in plants inoculated during the vegetative growth stage with adult WFT but were not affected when inoculation with immature WFT occurred during the reproductive stage, as most WFT were found feeding inside the nectariferous spurs of the flowers. Tissue $\mathrm{N}$ was lower in WFT-inoculated plants compared to noninoculated plants in both experiments.

Western flower thrips (Frankliniella occidentalis Pergande; WFT) is an insect pest of many field and greenhouse crops (Oetting et al., 1993; Robb, 1989). They use the maxillary stylets of their mouth cone to rasp or suck plant sap, resulting in the collapse of surrounding cells (Lewis, 1973; Chrisholm and Lewis, 1984;

Received for publication $23 \mathrm{Jan}$. 2003. Accepted for publication 11 Aug. 2003. This research was supported by grants from The Fred C. Gloeckner Foundation and F.I.R.S.T. (formerly Bedding Plants Foundation, Inc.). This manuscript has been Bedding Plants Foundation, Inc.). This manuscript has been assigned Contribution no. 03-157-J from the Kansas Agricultural Experiment Station (KAES). We thank Jim Nechols for discussion; David Margolies and Fengyou Jiafor assistance with cage design, Lea Westervelt for help with fertigation system construction; and Marci Spaw for help with sampling. We appreciate the statistical expertise provided by Tom Loughin. Appreciation is extended to Mike Uchneat and Pan American Seed Co. (West Chicago, Ill.) for providing impatiens seed. The use of trade names in this publication does not imply endorsement by the KAES of products named nor criticism of similar ones not mentioned.

${ }^{1}$ Graduate research assistant.

${ }^{2}$ Associate professor; to whom reprint requests should be directed.

${ }^{3}$ Professo

${ }^{4}$ Currently manager of horticultural research, SePRO Corp., 11550 North Meridian St., Suite 600, Carmel, IN 46032 4565 .

HortSCIEnce Vol. 39(3) June 2004 that may augment other control strategies is nutrition management.

Nutrition management is necessary for timely and profitable crop production, but at the same time, it changes plant nutrient content, morphology, and plant defense mechanisms against pests (Norris and Kogan, 1980; Suresh, 1988). Because manipulation of fertilizer is relatively easy in greenhouse production and compatible with biological control, it may increase the economic feasibility of biological control by reducing the potential for pest population increase. Previous studies suggest that, in general, phytophagous insect pests prefer plant tissue with increased nitrogen and protein and low carbohydrate and phenol content (Ananthakrishnan, 1992; McNeil, 1978). However, little research has been done to evaluate thrips-host-plant nutrition response (Mollema and Cole, 1996; Schuch et al., 1998), and no research has evaluated the role of $\mathrm{P}$ in this response.

Impatiens wallerana is an economically important spring bedding plant crop (NASS, 2001) and a major host plant of WFT. For this research, 'Dazzler Violet' was selected because of its uniform growth habit, dark petal coloration and lack of purple blotches on the abaxial surface of the foliage. Thrips damage on impatiens includes tan lesions on leaves, distortion of newly developed leaves and flowers, flower bud abortion, and discolored strips of cells on flower petals.

The objectives of this research were to 1 ) determine the effects of $\mathrm{N} \times \mathrm{P}$ fertilization regimes on tissue nutrient concentrations of impatiens and their sequential effect on WFT population levels, and 2) investigate the relationship between WFT population and feeding damage on impatiens during the vegetative and reproductive growth stages.

\section{Materials and Methods}

Two greenhouse experiments were conducted at Kansas State University in Manhattan. Experiment 1 was conducted from $15 \mathrm{Feb}$ to 1 June 2001, and Expt. 2 from 20 May to 24 Aug. 2001. Impatiens wallerana 'Dazzler violet' were propagated from seed in both experiments. A replacement cultivar, 'Improved Dazzler Violet,' was released in 2000 by Pan American Seed Co. (West Chicago, Ill.), but only 'Dazzler Violet' was used to maintain consistency with previous experiments (Williams, Bell, and Harbaugh, unpublished data).

Treatment structure was factorial with $2 \mathrm{~N}$ ( 8 and $20 \mathrm{~mm}$ ) by $2 \mathrm{P}(0.32$ and $1.28 \mathrm{~mm})$ by 2 WFT inoculation rates: 0 (no-WFT control) and 10 WFT per plant (WFT-inoculated) sampled over 4 weeks. Fertilizer rates were selected based on previous research and chosen because they resulted in high impatiens quality (based on plant size and aesthetic appearance) but variable tissue $\mathrm{N}$ and $\mathrm{P}$ concentrations (Jonas and Williams, unpublished data). Current fertilization recommendations for impatiens range from 7 to $18 \mathrm{~mm} \mathrm{~N}$ (Dole and Wilkins, 1999; Whipker et al., 1999). Therefore, nitrogen rates used in these experiments are within commercially practiced ranges. 
Experimental design was a randomized complete block (RCBD) with an unequal number of replications for the no-WFT control versus WFT-inoculated treatments. In Expt. 1 , four replications of WFT-inoculated treatments and two replications of no-WFT control reatments were blocked across a temperature gradient resulting from the use of evaporative cooling pads in a glass greenhouse. Because a primary purpose of no-WFT control plants was to determine tissue nutrient status ove 4 weeks of sampling, two replications was adequate. Each experimental unit consisted of four pots, and one was sampled weekly over a 4-week period following inoculation with WFT. Pots of WFT-inoculated plants were randomly placed along the fertigation tubes on each bench, and no-WFT control plants were arranged as subplots along side the WFT-inoculated plants to receive the corresponding fertilizer treatment. Combinations ofWFT-inoculated and no-WFT control plants that received the same nutrition treatment were statistically analyzed as whole plots.

The design of Expt. 2 was similar to Expt. 1 , except that the number of replications of WFTinoculated treatments was increased to eight, and the number of pots in an experimental unit of noWFT control treatments was two and sampled at only 2 and 4 weeks after inoculation.

In both experiments, four extra plants of each of the four nutrient treatment combinations were randomly placed throughout the experiment and sampled at the time of WFT inoculation to determine the starting point of their nutritional status. As a RCBD with an unequal number of blocks, PROC MIXED and LSMEANS was used for data analyses SAS, Cary, N.C.). This statistical procedure compares the computed adjusted means, so it accounts for different variance at each sample date.

Impatiens seeds were sown directly into 48 -cell packs $\left(130 \mathrm{~cm}^{3}\right.$ in volume) and grown in a $2.5 \times 1.2 \times 1.2-\mathrm{m}$ tent covered with $\mathrm{No}-$ thrips Insect Screen (Green.Tek, Inc., Edgerton, Wis.) to avoid natural infestation with WFT. Root medium consisted of a ratio of 7 sphagnum peatmoss (Premier, Red Hill, Pa.) 3 perlite (Lite-Weight Products, Kansas City, Kans.) that was amended with the following weights (in $\mathrm{kg} \cdot \mathrm{m}^{-3}$ ): 6 dolomitic limestone, 0.9 gypsum, and 0.9 Micromax (Scott-Sierra Co., Marysville, Ohio). Fertilizer applications began when seedlings developed two pairs of true leaves, on 12 Mar. and 2 July in Expts. 1 and 2 , respectively.

Plants were transplanted into 10-cm-round, green pots ( $480 \mathrm{~cm}^{3}$ in volume) when seedlings had four pairs of true leaves, on $1 \mathrm{Apr}$. and 16 July in Expt. 1 and 2, respectively. Pots were placed into individual cages that had been constructed from 19-L cardboard ice cream buckets (38 $\mathrm{cm}$ tall $\times 26 \mathrm{~cm}$ diameter round) with four $14 \times 27-\mathrm{cm}$ apertures cut into the sidewalls that were covered with No-Thrips Screen and sealed with silicone). About $460 \mu \mathrm{mol} \cdot \mathrm{s}^{-1} \cdot \mathrm{m}^{-2}$ supplemental irradiance from high-pressure sodium lamps (Sunlight Supply, Inc., Vancouver, Wash.) was provided from 1900 PM to 0000 $\mathrm{HR}$, resulting in a 16-h photoperiod. Irradiance inside the cage was $\approx 70 \%$ of the level outside the cage, which was adequate for impatiens growth. Greenhouse temperatures were set at $24{ }^{\circ} \mathrm{C}$ day and $18{ }^{\circ} \mathrm{C}$ night after transplant. HOBO (Onset Computer Corp., Bourne, Mass.) temperature sensors were used to record actual temperatures and relative humidity inside the cages every $30 \mathrm{~min}$. Temperatures ranged from 14 to $37^{\circ} \mathrm{C}$, with an average daily temperature of $22{ }^{\circ} \mathrm{C}$ in Expt. 1 ; and 15 to $41^{\circ} \mathrm{C}$, with an average daily temperature of $26^{\circ} \mathrm{C}$ in Expt. 2 . Relative humidity ranged from 23 to $96 \%$ with average of $60 \%$ in Expt. 1; and 29 to $94 \%$ with an average of $66 \%$ in Expt. 2

Plants were grown in individual cages for 4 or 2 weeks before inoculation in Expts. 1 and 2 , respectively, and were fertigated by pumping (140 gal/h) fertilizer treatment solutions through spaghetti tubes to pots inside each sealed cage. Plants were fertigated when container capacity dropped by $30 \%$ due to water loss based on weights of representative plants that were grown using the same procedure, but cages for these plants were not sealed and they were weighed at least once a day to determine time of fertigation. Leaching fraction was maintained between $5 \%$ to $15 \%$. This methodology resulted in plants receiving fertilizer solution about once every the other day to almost daily as they reached maturity. The volume of fertilizer solution applied at each fertigation was recorded so that total nutrients applied could be calculated.

Western flower thrips were obtained from a laboratory colony maintained on green beans in the Dept. of Entomology, Kansas State Univ. (KSU), that was derived from a stock colony maintained by Diane Ullman (Dept. of Entomology, University of California-Davis) determined to be free of INSV and TSWV. The KSU colony was maintained under laboratory light conditions with temperatures set at 24 ${ }^{\circ} \mathrm{C}$ and relative humidity of $37 \%$. WFT of different life stages (first and second instar nymphs, pupae, and adult) were kept in separate containers. WFT inoculation in Expt. 1 was conducted 4 weeks after transplant on 1 May. Plants were in the reproductive growth stage with an average of 20 flowers per plant. Ten second-instar nymphs were transferred into a $2.5-\mathrm{mL}$ vial from the nymph stage colony by using a mini-brush. The vial was later opened and placed in the foliage canopy of a caged plant. In Expt. 2, nonflowering plants were inoculated with 10 adult female WFT 2 weeks after transplant on 30 July. Before inoculating plants, the adult WFT colony was placed in a 6 ${ }^{\circ} \mathrm{C}$ refrigerator for $20 \mathrm{~min}$ to slow movement. Female adults, which are broader and darker than males, were selected and placed into a 2.5-mL vial that was later opened and placed in leaves of a caged plant.

Plant growth data collected at each sample date included plant height, canopy width (the average of two measurements taken at right angles to each other), flower and bud numbers. Subjective damage ratings were assigned to individual plants based on a scale of 1 to 5 , where 1 = slightly observable leaf stippling, 2 = observable leaf distortion and tan lesion development, 3 = significant leaf distortion and tan lesion development, 4 = severe leaf distortion and tan lesion development with flower bud abortion, and $5=$ severe leaf damage and flower bud abortion with stunted growth. The number of damaged leaves was also counted in Expt. 2, and the relationship between number of damaged leaves and visual damage ratings was positively correlated $\left(\mathrm{n}=160, r^{2}=0.77\right.$ $\mathrm{y}=0.2+0.06 \mathrm{x}$; data not shown). For control plants, ratings were determined on the same plant for weeks 1 and 2, and similarly on the same plant for weeks 3 and 4, before that plant was destructively harvested.

To count WFT, caged plants were placed in a $6{ }^{\circ} \mathrm{C}$ refrigerator for $20 \mathrm{~min}$ to slow insect movement before removing the plant from the cage for destructive harvest. Immature and adult WFT were counted separately. Shoots were placed in a $41 \times 29 \times 25 \mathrm{~cm}$ clear plastic box (Rubbermaid Home Products, Wooster, Ohio) and uniformly shaken; WFT in flowers and buds were individually counted by destructively peeling back petals; terminal meristems were individually rinsed in a $48 \%$ ethanol stream and WFT collected were counted. Yellow sticky cards were placed in the cage with the pot and counted 2 weeks later. Adults found on sticky cards were counted as immatures because that was their life stage at the time of plant sampling. Total WFT number was the sum of adults and immatures.

Tissue samples consisted of $\approx 10 \mathrm{~g}$ fresh weight of leaf blades of youngest, fully expanded leaves from midcanopy foliage. Tissue was washed in $0.2 \mathrm{~N} \mathrm{HCl}$ and distilled water and dried at $70{ }^{\circ} \mathrm{C}$ for $48 \mathrm{~h}$, then ground in a stainless-steel Wiley mill to a particle size of $<1 \mathrm{~mm}$. Nitrogen was determined by dry combustion using a carbon-nitrogen analyzer (CN-2000; LECO Corp., St. Joseph, Minn.). Some of the leaf samples were dry-ashed at $500{ }^{\circ} \mathrm{C}$, dehydrated in $6 \mathrm{~mol} \cdot \mathrm{L}^{-1} \mathrm{HCl}$, and dissolved in $0.5 \mathrm{~mol} \cdot \mathrm{L}^{-1} \mathrm{HCl}$, and $\mathrm{K}, \mathrm{Ca}$, and $\mathrm{Mg}$ were then analyzed using an inductivelycoupled argon plasma atomic emission spectrophotometer (ICP-AES; Fisons Instruments, Dearborn, Mich.). Phosphorus was determined by the molybdate-vanadate colorimetric method (Chapman and Pratt, 1961) using a UV-VIS spectrophotometer (Perkin-Elmer, Norwalk, Conn.).

\section{Results}

In both experiments, significantly different tissue $\mathrm{N}$ and $\mathrm{P}$ concentrations were established at the time of inoculation (Table 1). The $\mathrm{N} \times$ $\mathrm{P}$ interaction was not significant in either experiment. In Expt. 1, tissue P was $0.29 \%$ and $0.62 \%$ in plants fertilized with 0.32 and 1.28 $\mathrm{mm} \mathrm{P}$, respectively; whereas in Expt. 2, tissue $\mathrm{P}$ was $0.48 \%$ and $0.88 \%$ for these two $\mathrm{P}$ rates, respectively (Table 1). Plants were at different growth stages at the time of inoculation, so it is not surprising that tissue $\mathrm{P}$ concentrations were lower in Expt. 1 (reproductive growth stage) compared to Expt. 2 (vegetative growth stage)

Inoculation during reproductive stage (Expt. 1). During the 4-week period after inoculation, the no-WFT control plants fertilized 
with different $\mathrm{N}$ and $\mathrm{P}$ treatment combinations resulted in similar, commercially acceptable growth based on plant height, width, and number of flowers. Dry weight was slightly different between plants fertilized with 0.32 and $1.28 \mathrm{~mm} \mathrm{P}$ (Table 2). The $\mathrm{N} \times \mathrm{P}$ interaction was not significant for growth responses and results were similar to previous single factor $\mathrm{N}$ and $\mathrm{P}$ experiments (Jonas and Williams, unpublished data).

Tissue concentrations of $\mathrm{N}$ and $\mathrm{P}$ in no-WFT control plants were significantly different: 8 and $20 \mathrm{~mm} \mathrm{~N}$ rates resulted in $4.8 \%$ and $6.3 \%$ tissue $\mathrm{N}$ (Table 2), which represents adequate (within the range of critical tissue concentrations that results in maximum growth) and luxurious (exceeding the range of critical tissue concentrations without decreasing growth), respectively (e.g., Jacques et al., 1992; Mills and Jones, 1996; Jonas and Williams, unpublished data). The 0.32 and $1.28 \mathrm{~mm} \mathrm{P}$ rates resulted in $0.29 \%$ and $0.66 \%$ tissue $P$, which represents adequate tissue $\mathrm{P}$ concentrations (e.g., van Iersel et al., 1998; Jonas and Williams, unpublished data). Therefore, different tissue $\mathrm{N}$ and $\mathrm{P}$ were established throughout the experiment that provided a variable diet for WFT across treatments.

The total number of WFT generally increased over the 4-week period after inoculation. Neither $\mathrm{N}$ nor $\mathrm{P}$ treatments had a significant effect on WFT populations when the data were analyzed over 4 weeks (for $\mathrm{N}$ : $\mathrm{F}=0.01, \mathrm{df}=64, p=0.9647$; for $\mathrm{P}: \mathrm{F}=0.48$, $\mathrm{df}=64, p=0.4930, \alpha=0.1)$. However, during week three, higher WFT numbers were found on high $P$ compared to low $P$ plants $(F=4.08$, $\mathrm{df}=16, p=0.0143, \alpha=0.1$, Table 3 )

In this experiment, inoculation with immature WFT occurred when plants were in the reproductive stage. An average of 20 flowers were fully open per plant when inoculation occurred. Feeding damage from WFT was not significant compared to the no-WFT control plants until three weeks after inoculation $(\mathrm{F}=$ $4.8, \mathrm{df}=16, p=0.0436, \alpha=0.05)$. At week 4, the average damage rating of all WFT-inoculated plants was only 0.6 (Fig. 1).

When comparing WFT-inoculated versus no-WFT control plants at the end of the experiment, plants were similar in height, width, and dry weight (Table 4). Tissue $\mathrm{N}$ in inoculated plants was lower than in control plants, suggesting that WFT feeding reduced $\mathrm{N}$ uptake and utilization. However, tissue concentrations of $\mathrm{P}, \mathrm{K}, \mathrm{Ca}$, and $\mathrm{Mg}$ were not affected by WFT feeding (Table 4).

Inoculation during vegetative stage (Expt. 2). The no-WFT control plants fertilized with different $\mathrm{N}$ and $\mathrm{P}$ treatment combinations resulted in similar, commercially acceptable growth based on all measured characteristics (Table 5). Tissue $\mathrm{N}$ concentration was significantly different between the 8 and $20 \mathrm{~mm} \mathrm{~N}$ treatments, resulting in $4.9 \%$ and $6.3 \%$ tissue $\mathrm{N}$, respectively (Table 5). The $\mathrm{N} \times \mathrm{P}$ interaction was significant for tissue $\mathrm{N}: 8 \mathrm{~mm}$ N resulted in a lower $\mathrm{N} \%$ at the high $\mathrm{P}$ level (1.28 mM) than at the low Plevel $(0.32 \mathrm{~mm})$, while the opposite was true for the $20 \mathrm{~mm} \mathrm{~N}$ treatments; however, the $\mathrm{N}$ main effect was not affected. These tissue
Table 1. Plant tissue $\mathrm{N}$ and $\mathrm{P}$ concentrations in plants fertilized with $2 \mathrm{~N} \times 2 \mathrm{P}$ treatments. Samples were collected at the time of inoculation on 2 May (Expt. 1) and 30 July 2001 (Expt. 2).

\begin{tabular}{|c|c|c|c|c|}
\hline \multirow[b]{3}{*}{ Treatment } & \multicolumn{2}{|c|}{ Expt. 1} & \multicolumn{2}{|c|}{ Expt. 2} \\
\hline & $\mathrm{N}$ & $\mathrm{P}$ & $\mathrm{N}$ & $\mathrm{P}$ \\
\hline & $(\%)$ & $(\%)$ & $(\%)$ & $(\%)$ \\
\hline \multicolumn{5}{|l|}{$\overline{p \text { value }^{2}}$} \\
\hline $\mathrm{N}$ & 0.0173 & 0.1788 & $<0.0001$ & 0.2339 \\
\hline $\mathrm{P}$ & 0.9423 & 0.0013 & 0.0136 & 0.0277 \\
\hline \multicolumn{5}{|l|}{$\mathrm{N}$} \\
\hline $8 \mathrm{~mm}$ & 5.0 & 0.49 & 4.8 & 0.76 \\
\hline $20 \mathrm{~mm}$ & 6.3 & 0.42 & 6.2 & 0.60 \\
\hline $\operatorname{LSD}_{0.05^{y}}{ }^{y}$ & 0.9 & NS & 0.1 & NS \\
\hline \multicolumn{5}{|l|}{$\mathrm{P}$} \\
\hline $0.32 \mathrm{~mm}$ & 5.7 & 0.29 & 5.6 & 0.48 \\
\hline $1.28 \mathrm{~mm}$ & 5.7 & 0.62 & 5.4 & 0.88 \\
\hline $\mathrm{LSD}_{0.05}$ & NS & 0.12 & 0.1 & 0.32 \\
\hline
\end{tabular}

${ }^{2} \mathrm{~N} \times \mathrm{P}$ interaction was not significant in either experiment

${ }^{y}$ Least significant difference for comparing two $\mathrm{N}$ or $\mathrm{P}$ rates at $\alpha=0.05, \mathrm{n}=4$.

Table 2. Growth responses and tissue $\mathrm{N}$ and $\mathrm{P}$ concentrations in no-WFT control plants averaged over fou sample dates (1 to 4 weeks after inoculation) during the reproductive growth stage (Expt. 1).

\begin{tabular}{|c|c|c|c|c|c|c|}
\hline Treatment & $\begin{array}{l}\mathrm{Ht} \\
(\mathrm{cm})\end{array}$ & $\begin{array}{l}\text { Width } \\
(\mathrm{cm})\end{array}$ & $\begin{array}{l}\text { Dry } \\
\text { wt } \\
(\mathrm{g})\end{array}$ & $\begin{array}{l}\text { No. of } \\
\text { flower } \\
\text { buds }\end{array}$ & $\begin{array}{c}\mathrm{N} \\
(\%)\end{array}$ & $\begin{array}{c}\mathrm{P} \\
(\%)\end{array}$ \\
\hline \multicolumn{7}{|l|}{$\overline{p \text { value }^{z}}$} \\
\hline $\mathrm{N}$ & 0.8819 & 0.3743 & 0.4441 & 0.8987 & 0.0001 & 0.3322 \\
\hline $\mathrm{P}$ & 0.2482 & 0.4310 & 0.0229 & 0.1049 & 0.3838 & 0.0001 \\
\hline \multicolumn{7}{|l|}{$\mathrm{N}$} \\
\hline $8 \mathrm{~mm}$ & 11.0 & 29.0 & 2.9 & 29.4 & 4.8 & 0.46 \\
\hline $20 \mathrm{~mm}$ & 11.2 & 23.3 & 3.1 & 29.0 & 6.3 & 0.48 \\
\hline $\operatorname{LSD}_{0.05}{ }^{y}$ & NS & NS & NS & NS & 0.4 & NS \\
\hline $0.32 \mathrm{~mm}$ & 10.7 & 29.6 & 2.7 & 26.3 & 5.6 & 0.29 \\
\hline $1.28 \mathrm{~mm}$ & 11.6 & 23.7 & 3.2 & 31.1 & 5.5 & 0.66 \\
\hline $\mathrm{LSD}_{005}$ & NS & NS & 0.2 & NS & NS & 0.11 \\
\hline
\end{tabular}

${ }^{2} \mathrm{~N} \times \mathrm{P}$ interaction was not significant except for dry weight $(p=0.0242)$

${ }^{\mathrm{y}}$ Least significant difference for comparing two $\mathrm{N}$ or $\mathrm{P}$ rates at $\alpha=0.05, \mathrm{n}=16$.

Table 3. Total number of WFT on inoculated plants at four sample dates after inoculation during the reproductive growth stage (Expt. 1) for P fertilizer treatments.

\begin{tabular}{|c|c|c|c|c|}
\hline \multirow[b]{2}{*}{ Treatment } & \multicolumn{4}{|c|}{ Total WFT / plant } \\
\hline & $\overline{\text { Week } 1}$ & Week 2 & Week 3 & Week 4 \\
\hline \multicolumn{5}{|l|}{$p$ value } \\
\hline $\mathrm{N}$ & 0.7763 & 0.5409 & 0.5999 & 0.2136 \\
\hline $\mathrm{P}$ & 0.2500 & 0.4122 & 0.0143 & 0.3555 \\
\hline \multicolumn{5}{|l|}{$\mathrm{P}$} \\
\hline $0.32 \mathrm{~mm}$ & 9 & 25 & 23 & 88 \\
\hline $1.28 \mathrm{~mm}$ & 14 & 34 & 53 & 48 \\
\hline Standard error ${ }_{01}^{\mathrm{z}}$ & NS & NS & \pm 7 & NS \\
\hline
\end{tabular}

${ }^{2}$ Standard error for the LSMEANS of P treatments at $\alpha=0.1, \mathrm{n}=8$.

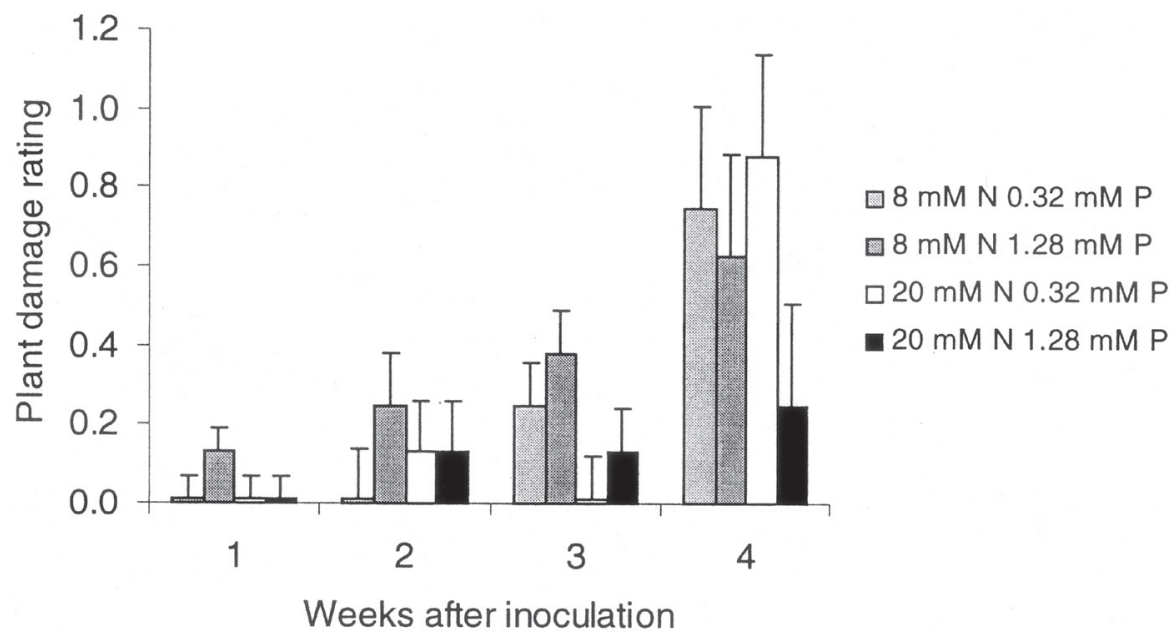

Fig. 1. Plant damage ratings over 4 weeks after inoculating with immature WFT during the reproductive growth stage (Expt. 1). Bars represent SE at each sample date; $n=4$. 


\section{Pest Management}

Table 4. Growth responses and tissue N, P, K, Ca, and Mg concentrations in WFT-inoculated and no-WFT control plants averaged over two sample dates (2 and 4 weeks after inoculation) during the reproductive growth stage (Expt. 1).

\begin{tabular}{|c|c|c|c|c|c|c|c|c|c|}
\hline Treatment & $\begin{array}{c}\mathrm{Ht} \\
(\mathrm{cm})\end{array}$ & $\begin{array}{l}\text { Width } \\
(\mathrm{cm})\end{array}$ & $\begin{array}{l}\text { No. of } \\
\text { flower } \\
\text { buds }\end{array}$ & $\begin{array}{l}\text { Dry } \\
w t \\
(\mathrm{~g})\end{array}$ & $\begin{array}{c}\mathrm{N} \\
(\%)\end{array}$ & $\begin{array}{c}\mathrm{P} \\
(\%)\end{array}$ & $\begin{array}{c}\mathrm{K} \\
(\%)\end{array}$ & $\begin{array}{l}\mathrm{Ca} \\
(\%)\end{array}$ & $\begin{array}{l}\mathrm{Mg} \\
(\%)\end{array}$ \\
\hline$\overline{p \text { value }}$ & 0.6813 & 0.0783 & 0.4152 & 0.9663 & 0.0466 & 0.6596 & 0.2702 & 0.2349 & 0.2821 \\
\hline No-WFT control & 11.2 & 23.1 & 29.2 & 3.0 & 5.54 & 0.47 & 2.17 & 2.02 & 0.64 \\
\hline $\operatorname{LSD}_{0,05}{ }^{\mathrm{z}}$ & NS & NS & NS & NS & 0.13 & NS & NS & NS & NS \\
\hline
\end{tabular}

${ }^{2}$ Least significant difference for comparing WFT-inoculated and no-WFT control plants, $n=16$ for WFT-inoculated plants and $n=8$ for no-WFT control plants.

Nconcentrations represent optimum and luxurious consumption of $\mathrm{N}$ as described in Expt. 1. Tissue Pin control plants fertilized with 0.32 and $1.28 \mathrm{~mm} P$ was $0.37 \%$ and $0.77 \%$, respectively (Table 5), which represents adequate tissue $\mathrm{P}$ concentrations (e.g., van Ierseletal., 1998; Jonas and Williams, unpublished data). Therefore, as in Expt. 1, test plants were of similar size but provided different diets for WFT.

The relationship between WFT population levels and nutrient treatments was statistically analyzed based on the number of adult, immature, and total WFT (sum of immature and adul WFT) separately at each sample date, as well as over the entire 4-week period. The number of adult WFT and total WFT in plants fertilized with $1.28 \mathrm{~mm} P$ was significantly higher than in plants fertilized with $0.32 \mathrm{~mm}$ over 4 weeks $(\mathrm{F}=$ $4.0, \mathrm{df}=105, p=0.0481$, and $\mathrm{F}=3.03, \mathrm{df}=105$ $\mathrm{p}=0.0846$, respectively, $\alpha=0.1$, Table 6 ). The number of immature WFT $(\mathrm{F}=2.5, \mathrm{df}=105, p=$ 0.1170 , Table 6) showed a similar trend, but the differences were not significant. $\mathrm{N}$ application rates had no effect on WFT population levels ( $\mathrm{F}$ $=0.03, \mathrm{df}=105, p=0.8578$, Table 6).

Because inoculation occurred during the vegetative growth stage, WFT fed on foliage extensively; therefore, compared to the no-WFT control plants, significant damage was observed only 1 week after inoculation $(\mathrm{F}=53.05, \mathrm{df}=$ $21, p=0.0008)$, and damage ratings generally increased during the 4 weeks after inoculation (Fig. 2). At the end of experiment, some plants received a rating of 5 , indicating severe feeding injury that made them unsalable. However, severity of feeding damage did not differ across $\mathrm{N} \times \mathrm{P}$ treatments $(\mathrm{F}=1.68, \mathrm{df}=105, p=$ $0.1975)$. When compared with control plants, WFT-inoculated plants were shorter and had smaller width and fewer flowers buds; however, dry weight did not differ (Table 7).

Feeding by WFT resulted in significantly lower tissue N, but not tissue $\mathrm{P}$ (Table 7). This result is similar to what occurred in Expt. 1 when plants were inoculated during the reproductive stage with immature WFT (Table 4). This result suggests that feeding by WFT might alter the uptake and utilization of $\mathrm{N}$ to a greater extent than that of $\mathrm{P}$. However, within a range of commercially acceptable plant growth, tissue $\mathrm{P}$ concentration, as a component of the diet of WFT, has a greater impact on the physiology of the WFT than tissue N. WFT feeding did not affect tissue concentrations of $\mathrm{K}, \mathrm{Ca}$, or Mg (Table 7).

Damage among nutrient treatment combinations did not differ in either experiment over four sample dates. When comparing damage among nutrient treatment combinations by week, no differences were observed at most sample dates.

Table 5. Growth responses and tissue N and P concentrations in no-WFT control plants averaged over two sample dates ( 2 and 4 weeks after inoculation) during the vegetative growth stage (Expt. 2).

\begin{tabular}{|c|c|c|c|c|c|c|}
\hline Treatment & $\begin{array}{l}\mathrm{Ht} \\
(\mathrm{cm})\end{array}$ & $\begin{array}{c}\text { Width } \\
(\mathrm{cm})\end{array}$ & $\begin{array}{l}\text { Dry } \\
w t \\
(\mathrm{~g})\end{array}$ & $\begin{array}{c}\text { No. of } \\
\text { flower } \\
\text { buds }\end{array}$ & $\begin{array}{l}\mathrm{N} \\
(\%)\end{array}$ & $\begin{array}{c}\mathrm{P} \\
(\%)\end{array}$ \\
\hline \multicolumn{7}{|l|}{$\overline{p \text { value }}{ }^{z}$} \\
\hline $\mathrm{N}$ & 0.1407 & 0.6393 & 0.7557 & 0.6373 & 0.0002 & 0.102 \\
\hline $\mathrm{P}$ & 0.9806 & 0.4084 & 0.8783 & 0.4195 & 0.7932 & 0.000 \\
\hline \multicolumn{7}{|l|}{$\mathrm{N}$} \\
\hline $8 \mathrm{~mm}$ & 11.0 & 16.2 & 1.07 & 41.3 & 4.9 & 0.53 \\
\hline $20 \mathrm{~mm}$ & 9.4 & 15.6 & 1.01 & 37.9 & 6.3 & 0.61 \\
\hline $\operatorname{LSD}_{0.05}{ }^{y}$ & NS & NS & NS & NS & 0.4 & NS \\
\hline \multicolumn{7}{|l|}{$\mathrm{P}$} \\
\hline $0.32 \mathrm{~mm}$ & 10.2 & 16.4 & 1.05 & 42.5 & 5.7 & 0.37 \\
\hline $1.28 \mathrm{~mm}$ & 10.2 & 15.4 & 1.03 & 36.6 & 5.6 & 0.77 \\
\hline $\mathrm{LSD}_{005}$ & NS & NS & NS & NS & NS & 0.11 \\
\hline
\end{tabular}

${ }^{2} \mathrm{~N} \times \mathrm{P}$ interaction was not significant except for tissue $\mathrm{N} \%$, but the pattern of interaction would not affect $\mathrm{N}$ treatment effect at either $\mathrm{P}$ level.

${ }^{\mathrm{y}}$ Least significant difference for comparing two $\mathrm{N}$ or $\mathrm{P}$ rates at $\alpha=0.05, \mathrm{n}=8$.

Table 6. Number of adult, immature, and total western flower thrips (WFT) on WFT-inoculated plants averaged over four sample dates after inoculation during the vegetative growth stage (Expt. 2).

\begin{tabular}{|c|c|c|c|}
\hline \multirow[b]{2}{*}{ Treatment } & \multicolumn{3}{|c|}{ No. of WFT/plant } \\
\hline & Adult & Immature & Total \\
\hline$\overline{p \text { value }}$ & & & \\
\hline $\mathrm{N}$ & 0.5571 & 0.9231 & 0.8578 \\
\hline $\mathrm{P}$ & 0.0481 & 0.1170 & 0.0846 \\
\hline $\mathrm{P}$ & & & \\
\hline $0.32 \mathrm{~mm}$ & 17 & 71 & 88 \\
\hline $1.28 \mathrm{~mm}$ & 22 & 90 & 112 \\
\hline Standard error ${ }^{\mathrm{z}}$ & \pm 2 & NS & \pm 15 \\
\hline
\end{tabular}

${ }^{2}$ Standard error for the LSMEANS of P treatments at $\alpha=0.1, n=64$

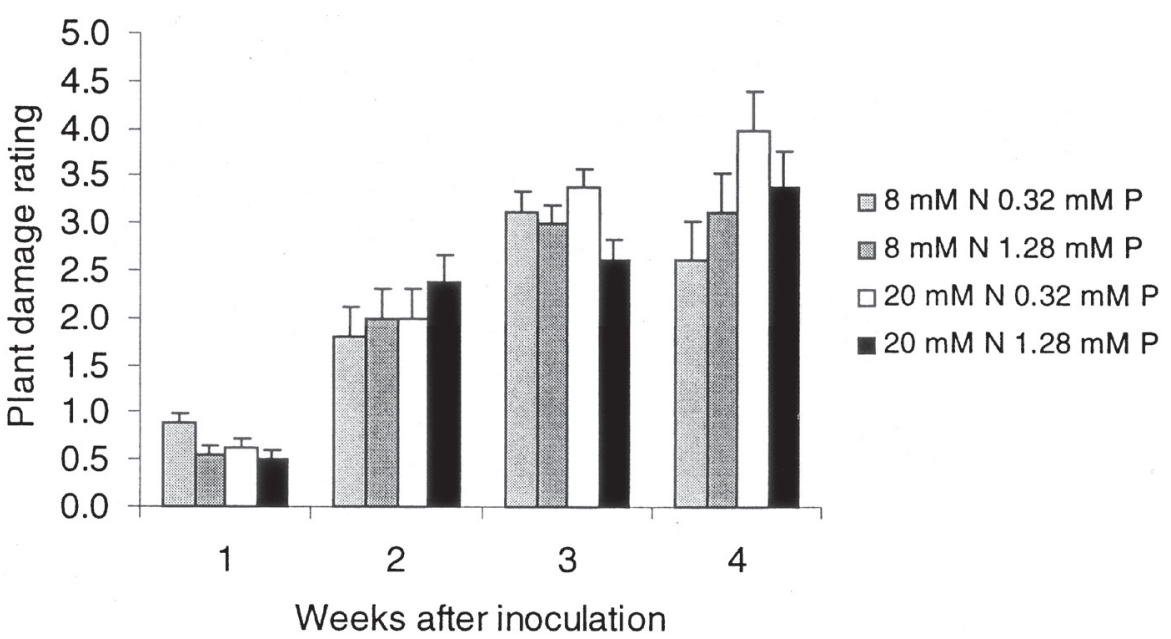

Fig. 2. Plant damage ratings over 4 weeks after inoculating with adult female WFT during the vegetative growth stage (Expt. 2). Bars represent SE at each sample date; $\mathrm{n}=8$.

Therefore, despite a trend of increase in WFT population with increasing foliar P concentration, we did not observe a significant increase in aesthetic damage.

\section{Discussion}

It is generally believed that supplementary $\mathrm{N}$ in plants results in enhanced health, growth, reproduction, and survival of most 
Table 7. Growth responses and tissue N, P, K, Ca, and Mg concentrations in western flower thrips (WFT)-inoculated plants and no-WFT control plants averaged over two sample dates ( 2 and 4 weeks after inoculation) during the vegetative growth stage (Expt. 2).

\begin{tabular}{|c|c|c|c|c|c|c|c|c|c|}
\hline Treatment & $\begin{array}{l}\mathrm{Ht} \\
(\mathrm{cm})\end{array}$ & $\begin{array}{l}\text { Width } \\
(\mathrm{cm})\end{array}$ & $\begin{array}{l}\text { No. of } \\
\text { flower } \\
\text { buds }\end{array}$ & $\begin{array}{l}\text { Dry } \\
\text { wt } \\
(\mathrm{g})\end{array}$ & $\begin{array}{c}\mathrm{N} \\
(\%)\end{array}$ & $\begin{array}{c}\mathrm{P} \\
(\%)\end{array}$ & $\begin{array}{c}\mathrm{K} \\
(\%)\end{array}$ & $\begin{array}{c}\mathrm{Ca} \\
(\%)\end{array}$ & $\begin{array}{l}\mathrm{Mg} \\
(\%)\end{array}$ \\
\hline$\overline{p \text { value }}$ & 0.0398 & 0.0356 & 0.0058 & 0.2332 & 0.0321 & 0.0633 & 0.0569 & 0.4809 & 0.1111 \\
\hline No-WFT control & 10.1 & 15.8 & 40 & 1.04 & 5.56 & 0.59 & 2.61 & 1.80 & 0.61 \\
\hline $\operatorname{LSD}_{0.05}{ }^{\mathrm{z}}$ & 0.5 & 1.1 & 4.6 & NS & 0.2 & NS & NS & NS & NS \\
\hline
\end{tabular}

arthropod species (Mattson, 1980), including arthropod species (Mattson, 1980), including
thrips (Ananthakrishnan, 1993). Reports of a positive relationship between phytophagous arthropod response and increased $\mathrm{N}$ are often based on experiments where insect responses to plants deficient in $\mathrm{N}$ are compared to plants with sufficient or luxurious $\mathrm{N}$ concentrations (e.g., Bethke et al., 1987; Schuch et al., 1998; Wermelinger et al., 1985). In our research, a difference in WFT population was not observed between the high versus low N plants, probably because no N-deficient plants were tested. Plants produced by both $\mathrm{N}$ regimes were of commercial quality, but contained significantly different foliar $\mathrm{N}$ concentrations from optimal to luxurious. These results indicate that within the range of $\mathrm{N}$ fertility that produces commercially-acceptable impatiens plants, increasing foliar $\mathrm{N}$ concentration does not support a significant increase in WFT populations. From a practical standpoint, this suggests that growers need not be concerned about an enhanced WFT response from overapplication of $\mathrm{N}$.

However, feeding by WFT significantly decreased tissue $\mathrm{N}$ concentration of impatiens compared to no-WFT control plants in both experiments: tissue $\mathrm{N}$ in plants with WFT for 4 weeks was $0.13 \%$ to $0.26 \%$ lower than control plants at both optimum and luxurious $\mathrm{N}$ fertilizer levels. A number of plant responses to feeding by WFT could have contributed to this outcome, including indirect disruption of $\mathrm{N}$ uptake, assimilation, and translocation in relation to a reduction in whole-plant photosynthesis.

Plant growth (except for dry weight) was affected by WFT feeding only in Expt. 2, when plants in the vegetative stage were inoculated with adult WFT, so these WFT fed on leaf and meristematic tissue. The rate of photosynthesis is decreased by epidermal feeders such as thrips (Welter, 1989). Individual cases of WFT feeding resulting in reduced photosynthesis have been reported for impatiens (Buntin etal., 1988) and cucumber (Cucumis sativus L.) (Hao et al., 2002). Buntin et al. (1988) speculated that mechanical disruption of chlorophyll-containing mesophyll cells occurs by thrips feeding and that this damage is the primary mechanism by which photosynthesis is reduced. Hao et al. (2002) reported that a reduced photosynthetic rate from WFT feeding occurred only after exposure to extremely large populations; therefore, they proposed that a reduction in leaf area was the main mechanism by which thrips feeding reduced whole plant photosynthesis. These mechanisms of photosynthesis reduction are different than reports of stomatal closure caused by other phytophagous feeders such as spider mites (e.g., DeAngelis et al., 1982).

In Expt. 1, when plants in the reproductive stage were inoculated with immature WFT, plant growth was not smaller in inoculated versus no-WFT control plants. This likely reflects the preferred feeding site in the reproductive stage, which is the nectariferous spur of the flowers. WFT are flower dwellers on many crops as they feed on pollen and nectar (Kirk, 1988). This was observed in our research, where $63 \%$ of the total number of WFT were found inside of the nectariferous spurs of the open flowers in Expt. 1. Unlike N, WFT feeding did not decrease tissue concentration of $\mathrm{P}$, $\mathrm{K}, \mathrm{Ca}$, or $\mathrm{Mg}$.

The effect of tissue $\mathrm{P}$ on arthropod populations has rarely been studied (e.g., Feller, 1995; Rodriguez, 1963; Wooldridge and Harrison, 1968), although $P$ is limited in nature and is an essential macronutrient. In all of the research conducted before 1989, the most common herbivore response to P-fertilized plants was no response (44\% of 50 cases), and the second most common response was positive (34\%) (Waring and Cobb, 1989). After this, a few studies postulated that a $\mathrm{P}$ effect occurred because of changes in secondary metabolites such as phenolics and terpenes. For example, Sun et al. (2000) observed a suppression in the population of pine tip moth [Rhyacionia frustrana (Comstock)] in loblolly pine (Pinus taeda L.) fertilized with $\mathrm{P}$, which may have been due to increased terpene composition of oleoresin. Research with the phytophagous twospotted spider mite (Tetranychus urticae Koch; TSM) indicated that its development and preoviposition period were slightly prolonged with $\mathrm{P}$ deficiency, and fecundity increased under moderate $\mathrm{P}$ shortage when the $\mathrm{N}$ concentration was the highest (Wermelinger et al., 1991).

In our research, there was a strong trend towards increased WFT population growth resulting from increased foliar $\mathrm{P}$ concentration. Plants under different treatments had varying $\mathrm{P}$ concentration but were of similar size and commercial quality, which suggests that the difference in WFT population was likely due to variable tissue $\mathrm{P}$ concentrations as opposed to the increased biomass production common with increasing rate of $\mathrm{P}$ fertilization. During feeding by WFT, epidermal cells are rasped apart and liquid contents are sucked up, resulting in collapse of cells surrounding the feeding site. This suggests that P-containing intracellular compounds such as nucleic acids, energy-transfer compounds like ADP and ATP, and P-storage compounds like polyphosphates are consumed by WFT. Since most WFT adults are females (Ananthakrishnan, 1979), an increase in the number of adults is strongly related to an increase in total WFT. Our research suggests that as tissue $\mathrm{P}$ concentration increases and becomes luxurious in plant cells, these plants may be a more beneficial nutrient source for WFT growth and development. Though not with a phytophagous insect, a study evaluating the $\mathrm{C}$ to $\mathrm{P}$ ratio of an artificial diet of mayflies (Caenis sp.) indicated that low $\mathrm{C}$ to $\mathrm{P}$ ratio food produced more rapid growth (Frost and Elser, 2002).

In both experiments, a wide range of visual damage from WFT feeding was observed over the 4-week period after inoculation. It is not possible to directly compare the results of the two experiments because different WFT life stages were used for inoculation. However, various life stages were present on a plant at the time of sampling due to the short developmental time of this pest. As a general observation, plants inoculated while in the vegetative stage with adults (Expt. 2) exhibited severe damage faster than plants that were inoculated in the reproductive stage with immature WFT (Expt. 1). In fact, plants were unsalable three weeks after vegetative-stage inoculation, but all plants were salable at the end of the production cycle when inoculated in the reproductive stage. This observation suggests that growth stage of the plant should be considered when deciding upon a thrips management program for impatiens. It is important to note, however, that these two experiments occurred during different seasons, and WFT population levels increased faster in Expt. 2, likely due to the warmer temperatures as well as inoculation with adult female WFT as opposed to immature WFT. Even so, concentrated feeding damage on foliage and meristematic tissues were only observed in Expt. 2.

Because aesthetic damage thresholds for ornamental crops are very low, IPM programs typically use low action thresholds. As examples, in one study, two thrips per yellow sticky card per week resulted in initiation of biological control (Jacobsen, 1993); and in another study, 18 thrips per blue sticky card per week were at the lower end of the damage threshold (Frey, 1993). Monitoring and scouting efforts early in the production cycle are most crucia for control of WFT before aesthetic damage occurs. Our experience suggests that damage thresholds for impatiens in the vegetative growth stage should be lower than for plants that already have open flowers. In fact, earlyflowering cultivars may provide an advantage of tolerance to WFT compared to cultivars with longer vegetative growth stages.

In the greenhouse industry, $\mathrm{P}$ fertilizer has been historically over-applied (Nelson, 1990), raising concerns about pollution associated 


\section{Pest Management}

with nutrient effluent. Our results provide evidence that growers should manage $P$ fertility to minimize luxurious accumulation of this nutrient because it may support more rapid growth of WFT populations. Nitrogen fertility within the range that produces commercially acceptable impatiens does not impact WFT populations.

\section{Literature Cited}

Allen, W.R. and A.B. Broadbent. 1986. Transmission of tomato spotted wilt virus in Ontario greenhouse by Frankliniella occidentalis. Can. J. Plant. Pathol. 8:33-38.

Ananthakrishnan, T.N. 1979. Biosystematics of Thysanoptera. Annu. Rev. Entomol. 24:159-83.

Ananthakrishnan, T.N. 1992. Dimensions of insect-plant interactions. Oxford \& IBH, New Delhi.

Ananthakrishnan, T.N. 1993. Bionomics of thrips Annu. Rev. Entomol. 38:71-92.

Bethke, J.A., M.I. Parrella, J.T. Trumble, and N.C. Toscano. 1987. Effect of tomato cultivar and fertilizer regime on the survival of Liriomyza trifolii (Diptera: Agromyzidae). J. Econ. Entomol. 80:200-203.

Buntin, G.D., R.D. Oetting, and J.W. Daniell. 1988. Response of leaf photosynthesis and water relations of impatiens and peach to thrips injury. J. Agr. Entomol. 5:169-177.

Chapman, H.D. and P.F. Pratt. 1961. Methods of analysis for soils, plants and waters, p. 169-70. Univ. Calif. Div. Dept. Agr. Sci.

Chrisholm, I.F. and T. Lewis. 1984. A new look at thrips (Thysanoptera) mouthparts, their action and effects of feeding on plant tissue. Bul. Entomol. Res. 74:663-675.

DeAngelis, J.D., K.C. Larson, R.E. Berry, and G.W Krantz. 1983. Photosynthesis, leaf conductance, and leaf chlorophyll content in spidermite (Acari: Tetranychidae)-injured peppermint leaves. Environ. Entomol. 12:345-348.

Dole, J.M. and H.F. Wilkins. 1999. Floriculture: principles and species. Prentice Hall, Uppe Saddle River, N.J.

Feller L.C. 1995. Effects of nutrient enrichment on growth and herbivory of dwarf red mangrove (Rhizophora mangle). Ecol. Monogr. 65(4): 477-505.

Frey, J.E. 1993. Damage threshold levels for western flower thrips, Frankliniella occidentalis (Perg.) (Thysanoptera: Thripidae) on ornamentals. Intl. Org. Biol. Control Noxious Animals and Plants [IOBC/OILB] W. Palaearctic Reg. Sec. [WPRS/SROP] Bul. 16(8):78-81.

Frost, P.C. and J.J. Elser. 2002. Growth responses of littoral mayflies to the phosphorus content of their food. Ecol. Lett. 5(2):232-240.

Hao, X., J.L. Shipp, K. Wang, A.P. Papadopoulos, and M.R. Binns. 2002. Impact of western flowe thrips on growth, photosynthesis and productivity of greenhouse cucumber. Scientia Hort. 92:3-4, $187-203$

Hunter, W.B., and D.E. Ullman. 1989. Analysis of mouthpart movements during feeding of Frankliniella occidentalis (Pergande) and F. schultzei Trybom(Thysanoptera:Thripidae). Intl. J. Insect Morpho. Embryol. 18(2-3):161-171.

Immaraju, J.A., T.D. Paine, J.A. Bethke, K.L. Robb, and J.P. Newman. 1992. Western flower thrips (Thysanoptera: Thripidae) resistance to insecticide in coastal California greenhouses. J. Entomol. Soc. Amer. 85(1):9-14.

Jacobson, R.J. 1993. Integrated pest management in spring bedding plants: a successful package for commercial crops. Bul. OILB-SROP. 16:8, $105-112$

Jacques, D.J., F.R. Gouin, and P.S. Konjoian. 1992. Nitrate fertilization and root media effects on growth and shelf-life of 'Honeycomb' marigolds and 'Novette Red' impatiens. J. Plant Nutr. 15(5):569-578.

Kirk, W.D. 1988. Assessing the effects of flower thrips. Acta Phytopathol. Entomol. Hungarica 23(3-4):295-300.

Lewis, T. 1973. Thrips, their biology, ecology and economic importance. Academic Press, London.

Lewis, T. (ed.). 1997. Thrips as crop pests. CAB Intl. Press, New York.

Mattson, W.J. 1980. Herbivory in relation to plant nitrogen content. Annu. Rev. Ecol. Syst., 11:119-161.

McNeil, S. and T.R.E. Southwood, 1978. The role of nitrogen in the development of insect/plant relationships. Chapter 4. In: J.B. Harborne (ed.). Biochemical aspects of plant and animal coevolution. Academic Press, New York.

Mills, H.A. and J.B. Jones, Jr. 1996. Plant analysis handbook II-A practical sampling, preparation, analysis, and interpretation guide. MicroMacro Publ., Inc., Athens, Ga.

Mollema, C. and R.A. Cole. 1996. Low aromatic amino acid concentrations in leaf proteins determine resistance to Frankliniella occidentalis in four vegetable crops. Entomol. Expt. et Applicata 78:325-333.

NationalAgricultural Statistics Service. 2001. United States Department of Agriculture floriculture crops 2000 summary. SpCr6-6 (01). USDA, Wash., D. C.

Nelson, P.V. 1990. Developing root management strategies to minimize water and fertilizer waste: the United States perspective with emphasis on surface applied nonrecirculated systems. Acta Hort. 272:175-184.

Norris, D.M. and M. Kogan. 1980. Biochemical and morphological bases of resistance, p. 23-61. In: F.G. Maxwell and P.R. Jennings (eds.). Breeding plants resistant to insects. Wiley, New York.

Oetting, R.D., R.J. Beshear, T.X. Liu, S.K. Braman, and J.R. Baker. 1993. Biology and identification f thrips on greenhouse ornamentals. Ga. Agr. Expt. Sta. Res. Bul. No. 414

Robb, K.L. 1989. Analysis of Frankliniella occidentalis (Pergande) as a pest of floricultural crops in California greenhouses. PhD diss. Univ. Calif., Riverside.

Rodriguez, J.G. 1963. Nutritional studies in the acarina. Acarologia 5:324-337.

Schuch, U.K., R.A. Redak, and J.A. Bethke. 1998 Cultivar, fertilizer, and irrigation affect vegetative growth and susceptibility of chrysanthemum to western flower thrips. J. Amer. Soc. Hort. Sci. 123(4):727-733

Sun, J.H., D.L. Kulhavy, and A. Rogues. 2000 Effects of fertilizer and herbicide application on nantucket pine tip moth infestation (Lep., Tortricidae). J. Appl. Entomol. 124:191-195.

Suresh, G. 1988. Plant natural products in relation to insect resistance-An analysis, p. 87-103. In: T.N. Ananthakrishnan (ed.). Dynamics of insect-plant interaction-Recent advances and future trends. Oxford and IBH. New Delhi.

Thompson, S.P., K.M. Heinz, C.E. Bogran, and P.C. Krauter. 2002. Tips for thrips. Greenhouse Grower 20(8):104-114.

Ullman, D.E., C.A. Casey, A.E. Whitfield, L.R.Campbell, K.L. Robb, R.B. Medeiros, T.L. German, and J.L. Sherwood. 1998. Thrips and tospoviruses: Present and future strategies for management. Proc. Brighton Crop Protection Conf. Pest and Dis. 2:391-400.

Van Iersel, M.W., R.B. Beverly, P.A. Thomas, J.G. Latimer, and H.A. Mills. 1998. Fertilizer effects on the growth of impatiens, petunia, salvia, and vinca plug seedlings. HortScience 33(4):678-682

Waring, G.L. and N.S. Cobb. 1989. The impact of plant stress on herbivore population dynamics, $\mathrm{p}$. 167-225. In: E.A. Bernays (ed.). Insect-plant interaction. vol. 6. CRC Press, Boca Raton, Fla

Welter, S.C. 1989. Arthropod impact on plant gas exchange, p. 135-147. In: E.A. Bernays (ed.). Insect-plant interaction. vol. 1. CRC Press, Boca Raton, Fla.

Wermelinger, B., J.J. Oertli, and V. Delucchi. 1985. Effect of host plant nitrogen fertilization on the biology of the two-spotted spider mite, Tetranychus urticae. Entomol. Expt. Appl., 38:23-28.

Wermelinger B., J.J. Oertli, and J. Baumgartner. 1991. Environmental factors affecting the life-table of Tetranychus urticae (Acari:Tetranychidae) III. Host-plant nutrition. Expt. Appl. Acarol. 12:259-274.

Whipker, B.E., S. Dasoju, M.S. Dosmann, and J. K. Iles. 1999. Effect of fertilizer concentration on growth of double impatiens. HortTechnology $9(3): 425-428$.

Wooldridge, A.W. and F.P. Harrison. 1968. Effects of soil fertility on abundance of green peach aphids on Maryland tobacco. J. Econ. Entomol. 61(2):387-391. 